\title{
Investigation of the Drying Conditions for Amidosulfuric Acid
}

\author{
Toshiaki AsakaI, ${ }^{* \dagger}$ Ryota MinegishI, ${ }^{* *}$ Norie InABA, $*$ Yutaka Ishimura, ${ }^{*}$ Mariko Murayama,* \\ and Tatsuhiko TANAKA** \\ *National Institute of Technology and Evaluation, 2-49-10, Nishihara, Shibuya-ku, Tokyo 151-0066, Japan \\ **Faculty of Engineering, Tokyo University of Science, 1-3, Kagurazaka, Shinjuku-ku, Tokyo 162-8601, Japan
}

\begin{abstract}
The drying conditions for primary standards of volumetric analysis have a significant effect on the titration results due to changes in the purity, stability and homogeneity. Amidosulfuric acid, a strong acid used as a reference material for volumetric analysis in Japan, was dried in a vacuum desiccator or heated at different temperatures, and then measured by Karl-Fischer titration, thermogravimetry/mass spectroscopy (TG-MS), ion chromatography and coulometric titration. The optimum drying conditions were at $50^{\circ} \mathrm{C}$ for $24 \mathrm{~h}$ with crushing.
\end{abstract}

(Received September 15, 2005; Accepted December 26, 2005)

\section{Introduction}

Volumetric analysis is one of the basic methods for determining the concentration of solutions using acidimetric, redox, chelatometric and precipitation reactions. Amidosulfuric acid is a strong acid and one of the reference materials for volumetric analysis regulated by the Japanese Industrial Standard (JIS), ${ }^{1}$ and is recommended as a primary standard in acid-base titrimetry by the Analytical Methods Committee. ${ }^{2}$ Due to the effects of the drying conditions on the titration results, a number of studies have focused on this area for stoichiometric standards $;{ }^{3}$ however, the conditions for amidosulfuric acid have not been sufficiently investigated. Although the conditions under reduced pressure in a vacuum desiccator at room temperature for $4-48 \mathrm{~h}$ are generally used, ${ }^{1,4,5}$ there has been no study on the dependency on drying by heating. In this paper, we demonstrate Karl-Fischer titration for measuring the water content of amidosulfuric acid dried in a vacuum desiccator, or heated at different temperatures and cooled in a desiccator over silica gel. Ion chromatography and coulometric titration were used for detecting the decomposition products and changes of the purity of amidosulfuric acid, respectively. There are some reports concerning the application of coulometric titration for amidosulfuric acid, in which the coulometric assay yields the acidimetric factors on an absolute basis, without reference materials, with highly precise results compared with other chemical methods. ${ }^{6,7}$ The optimum drying conditions and procedures are discussed based on the results of several measuring methods.

\section{Experimental}

\section{Reagents}

Analytical reagent-grade chemicals were used unless otherwise stated. Amidosulfuric acid used for TG-MS, ion

$\dagger$ To whom correspondence should be addressed.

E-mail: asakai-toshiaki@nite.go.jp chromatography and coulometric titration was obtained from Tomiyama Pure Chemical Industries, Ltd., as were reference materials for volumetric analysis that were compliant with JIS K 8005. Analytical reagent-grade amidosulfuric acid was used for Karl-Fischer titration due to the exceedingly small amount of water content of the reference materials.

\section{$T G-M S$}

Shimadzu TGA-50 thermogravimetry/mass spectroscopy equipment (TG-MS) (Shimadzu Corporation, Kyoto, Japan) was used for measuring the loss through heat, the amount of water content and the substances generated through increased temperature. Before and after crushing amidosulfuric acid in a platinum cell, about $95 \mathrm{mg}$ was heated in a flow of $50 \mathrm{ml} / \mathrm{min}$ helium gas from room temperature to $200^{\circ} \mathrm{C}$ at a rate of $20.0^{\circ} \mathrm{C} / \mathrm{min}$, maintained for $10 \mathrm{~min}$, and then cooled to room temperature.

\section{Karl-Fischer titration}

The amount of water content of dried amidosulfuric acid was observed with an AQ-7 Karl-Fischer titrator based on coulometric titration with Hydranal Aqualyte $\mathrm{RS}^{\circledR}$ consisting of iodine ion, sulfur dioxide, amines, $80 \mathrm{vol} \%$ methanol and 10 vol\% chloroform as a generator electrolyte and Aqualyte $\mathrm{CN}^{\circledR}$ as a counter-electrolyte (Hiranuma Sangyo Co., Ltd., Ibaraki, Japan). About $80 \mathrm{mg}$ of amidosulfuric acid, which had been dried below $2 \mathrm{kPa}$ in a vacuum desiccator with silica gel at room temperature for 24 or $48 \mathrm{~h}$, or heated at $50-80^{\circ} \mathrm{C}$ for $2-$ $48 \mathrm{~h}$, was weighed in units of $10 \mu \mathrm{g}$. The water content was measured in units of $0.1 \mu \mathrm{g}$ about 20 times under each condition. All Karl-Fischer titration measurements were carried out in a glove box under a nitrogen gas stream.

\section{Ion chromatography}

Ammonium hydrogen sulfate $\left(\mathrm{NH}_{4} \mathrm{HSO}_{4}\right)$, sulfate salt $\left(\mathrm{SO}_{4}{ }^{2-}\right)$ and diammonium imidodisulfonate $\left(\mathrm{NH}\left(\mathrm{NH}_{4} \mathrm{SO}_{3}\right)_{2}\right)$ are formed by hydrolysis and heating:2,8

$$
\mathrm{NH}_{2} \mathrm{SO}_{3} \mathrm{H}+\mathrm{H}_{2} \mathrm{O} \longrightarrow \mathrm{NH}_{4} \mathrm{HSO}_{4},
$$




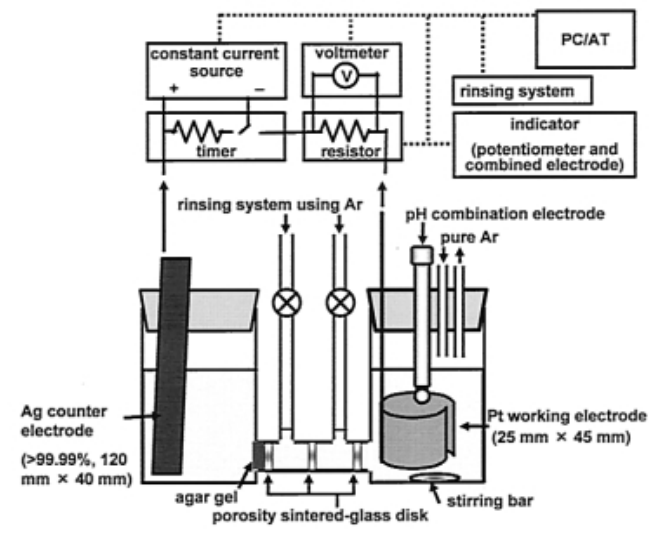

Fig. 1 Schematic diagram of the automated coulometric system.

$$
\begin{aligned}
& \mathrm{NH}_{2} \mathrm{SO}_{3} \mathrm{H}+\mathrm{H}_{2} \mathrm{O} \longrightarrow \mathrm{NH}_{4}{ }^{+}+\mathrm{SO}_{4}{ }^{2-}+\mathrm{H}^{+}, \\
& \mathrm{aNH}_{2} \mathrm{SO}_{3} \mathrm{H}+\mathrm{bO}_{2} \longrightarrow \mathrm{cNH}\left(\mathrm{NH}_{4} \mathrm{SO}_{3}\right)_{2}+\mathrm{dNO}_{\mathrm{x}}+\mathrm{eSO}_{\mathrm{x}} .
\end{aligned}
$$

The production of sulfate ions appears to indicate the decomposition of amidosulfuric acid. Ion chromatography was performed to obtain indications of its conversion by measuring the variation of sulfate ions under several drying conditions. Chromatograms were obtained using an IP 25 isocratic pump equipped with a CD 20 conductivity detector. IonPac ${ }^{\circledR}$ AS9-HC $(9 \mu \mathrm{m}, 4 \mathrm{~mm} \times 250 \mathrm{~mm})$ at an ambient temperature of $30^{\circ} \mathrm{C}$ was used to separate sulfate ions. Separation was achieved using an eluent of $9 \mathrm{mmol} / \mathrm{L}$ sodium carbonate. All equipment was obtained from Nippon Dionex K.K. (Osaka, Japan).

\section{Coulometric titration}

Amidosulfuric acid was crushed, dried at $50^{\circ} \mathrm{C}$ or $80^{\circ} \mathrm{C}$ for 24 $\mathrm{h}$ and cooled in a desiccator over anhydrous magnesium perchlorate for $30 \mathrm{~min}$. In addition, the purity of amidosulfuric acid dried under reduced pressure, below $2 \mathrm{kPa}$, in a vacuum desiccator with silica gel at room temperature for $48 \mathrm{~h}$, was determined. The formula weight used was 97.0946, the density $2.126 \mathrm{~g} / \mathrm{cm}^{3}$ and the Faraday constant $96485.338 \mathrm{C} / \mathrm{mol}$.

Figure 1 shows a schematic diagram of the automated coulometric titration system, which consists of a coulometric titration cell, an indicator, an electrolysis unit and a PC/ATbased control system. The amount of applied current was accurately calculated by a voltmeter and a standard resistor connected in series based on Ohm's law. All devices were controlled using coulometry software in a PC/AT-compatible computer, and an automated coulometric system achieved high repeatabilities and precision.

Both the supporting electrolyte and the anolyte consisted of about $100 \mathrm{ml}$ of $1 \mathrm{~mol} / \mathrm{L} \mathrm{KCl}$ solutions. The salt bridge was 0.1 $\mathrm{mol} / \mathrm{L} \mathrm{KCl}$ containing 3\% agar gel, and was prepared in advance. Sulfuric acid was added until approximately $\mathrm{pH}$ 5.0, then pre-titration was carried out using a small constant-current pulse $(2 \mathrm{~mA} \times 5 \mathrm{~s})$ of up to about $\mathrm{pH} 8.0$ in order to eliminate impurities dissolved in the supporting electrolyte. In the main titration, about $0.3 \mathrm{~g}$ of amidosulfuric acid, which was weighed in units of $1 \mu \mathrm{g}$ and to which a buoyancy correction was applied, was titrated by a large constant current $(120 \mathrm{~mA})$ of about $500 \mathrm{mC}$ before an inflection point. The end-point was, then determined in the same way as with pre-titration.

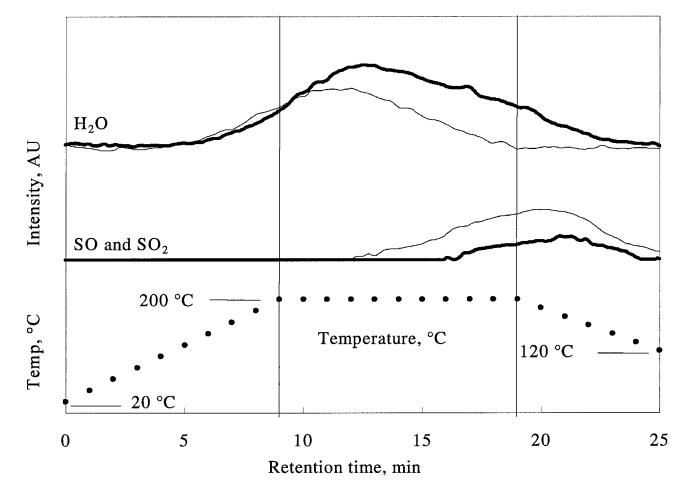

Fig. 2 Results of TG-MS. Before crushing, heavy line; after crushing, thin line; temperature, dotted line.

\section{Results and Discussion}

\section{$T G-M S$}

The loss through heat before crushing and after crushing amidosulfuric acid was $1.2 \%$ and $1.9 \%$, and the amount of the water content detected by a mass-spectrometer was $0.055 \%$ and $0.028 \%$ by weight, respectively. Figure 2 shows the results of TG-MS. The water content in either case of before and after crushing was released starting below $100^{\circ} \mathrm{C}$. Most of the weight lost through heat was caused by releasing sulfur monoxide and sulfur dioxide, which were produced by maintaining $200^{\circ} \mathrm{C}$. The weight lost before crushing was less than that after crushing; however, the amount of released water had the opposite results. The temperature for releasing water and other substances was inaccurate due to the exceedingly fast rising temperature; however, crushing the amidosulfuric acid led to an increase in its surface area, elimination of the water content and acceleration of decomposition at high temperature, qualitatively.

\section{Karl-Fischer titration}

The results concerning the water content under several drying conditions measured by Karl-Fischer titration are shown in Fig. 3. The water content of amidosulfuric acid without heating before crushing and after crushing was $0.0136 \%$ and $0.0086 \%$, respectively. This result reveals that the water content was released by only crushing, without any particular drying procedures, and was in good agreement with the results of a TG-MS analysis. By comparison, amidosulfuric acid without crushing after being dried by heat or under reduced pressure contained a significant water content; the crushing procedure led to a release of water included in the crystals.

The amount of water content under the drying conditions of heat or reduced pressure after crushing was lower than that of only crushing without heating or reduced pressure; consequently, heating or reducing the pressure were very effective drying procedures. Furthermore, longer drying times under the same temperature resulted in the release of a greater water content. The amount of water content under drying conditions of $50^{\circ} \mathrm{C}$ and $80^{\circ} \mathrm{C}$ for $24 \mathrm{~h}$ and $48 \mathrm{~h}$ was not significantly different, and was sufficient for releasing the water content, because about $0.003 \%$ of the water content was sufficiently small compared with the uncertainty of the weighing samples and the total volumetric analysis sequence.

\section{Ion chromatography}

The sulfate ion concentration detected by ion chromatography 


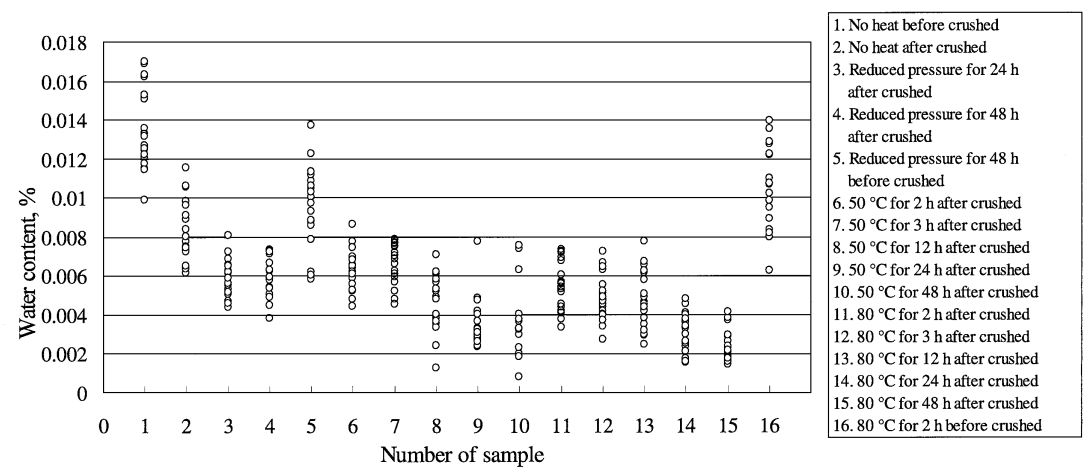

Fig. 3 Results of the water content measured by Karl-Fischer titration.

Table 1 Sulfate ion concentration detected by ion chromatography

\begin{tabular}{lcc}
\hline \multicolumn{1}{c}{ Drying condition } & Determined & $\begin{array}{c}\text { Mean value, } \\
\text { ppm }\end{array}$ \\
\hline No heat before crushed & 5 & 44 \\
No heat after crushed & 4 & 41 \\
$50^{\circ} \mathrm{C}$ for 2 $\mathrm{h}$ after crushed & 4 & 39 \\
$50^{\circ} \mathrm{C}$ for 24 h after crushed & 4 & 45 \\
$80^{\circ} \mathrm{C}$ for 2 $\mathrm{h}$ after crushed & 4 & 100 \\
$80^{\circ} \mathrm{C}$ for 24 h after crushed & 4 & 915 \\
Reduced pressure for 48 h after crushed & 6 & 39 \\
\hline
\end{tabular}

under several drying conditions is given in Table 1. The results concerning the concentration of sulfate ion without any particular drying procedures, no heat, were small and did not significantly differ from that at $50^{\circ} \mathrm{C}$ for $2 \mathrm{~h}$ or $24 \mathrm{~h}$ and under reduced pressure for $48 \mathrm{~h}$ after being crushed, due to the repeatability of ion chromatography and the experimental conditions; however, a significant amount of sulfate ions was detected at $80^{\circ} \mathrm{C}$ for $2 \mathrm{~h}$ and $24 \mathrm{~h}$ after crushing. Because ammonium hydrogen sulfate decomposed from amidosulfuric acid is a weaker acid, this leads to a small rise in the $\mathrm{pH}$. The production of ammonium hydrogen sulfate or sulfate ions change the acidimetric factors and the amount of impurities included in amidosulfuric acid; consequently, there is a significant effect on the volumetric or gravimetric titration results. The water content under the drying condition of $80^{\circ} \mathrm{C}$ was approximate at $50^{\circ} \mathrm{C}$; however, a significant amount of sulfate ions was detected in amidosulfuric acid dried under higher temperatures. Therefore, the drying condition of $80^{\circ} \mathrm{C}$ was found to be inappropriate.

\section{Coulometric titration}

Table 2 shows the results of the effective purity of amidosulfuric acid under several drying conditions demonstrated by coulometric titration. The results of no heat, $50^{\circ} \mathrm{C}$ for $24 \mathrm{~h}$ and reduced pressure for $48 \mathrm{~h}$ after crushing are approximate data: $99.954 \%, 99.956 \%$ and $99.955 \%$, respectively. However, the purity under the drying condition of $80^{\circ} \mathrm{C}$ for $24 \mathrm{~h}$ gave a lower result; consequently, this condition led to the production of ammonium hydrogen sulfate and sulfate ions and to an increased decomposition of amidosulfuric acid. The result of no heat before crushing, $99.966 \%$, was not significantly different from other results, except for that of $80^{\circ} \mathrm{C}$ for $24 \mathrm{~h}$; however, it was a slightly upper result. There were indications of the production of impurities, except for water by
Table 2 Results of purity demonstrated by coulometric titration

\begin{tabular}{lcc}
\hline \multicolumn{1}{c}{ Drying condition } & Determined & $\begin{array}{c}\text { Effective purities } \pm \\
\text { standard deviation, \% }\end{array}$ \\
\hline No heat before crushed & 9 & $99.966 \pm 0.012$ \\
No heat after crushed & 6 & $99.954 \pm 0.011$ \\
$50^{\circ} \mathrm{C}$ for $24 \mathrm{~h}$ after crushed & 5 & $99.956 \pm 0.003$ \\
$80^{\circ} \mathrm{C}$ for $24 \mathrm{~h}$ after crushed & 4 & $99.926 \pm 0.009$ \\
$\begin{array}{c}\text { Reduced pressure for } 48 \mathrm{~h} \\
\text { after crushed }\end{array}$ & 6 & $99.955 \pm 0.009$ \\
\hline
\end{tabular}

the crushing procedure or other influential impurities included in crystals for the effective purity of amidosulfuric acid.

\section{Conclusion}

We concluded that the optimum drying conditions were $50^{\circ} \mathrm{C}$ for $24 \mathrm{~h}$ with crushing because there were no indications of decomposition of amidosulfuric acid, and the conditions were sufficient for releasing the water content; longer drying times were unnecessary.

\section{Acknowledgements}

We express our gratitude for the TG-MS analysis demonstrated by Sumitomo Metal Technology, Inc., Japan.

\section{References}

1. JIS K 8005, "Reference Materials for Volumetric Analysis", 1999, Japanese Industrial Standards Committee, Tokyo.

2. Analytical Methods Committee, Analyst, 1967, 92, 587.

3. T. Yoshimori and N. Sakaguchi, Talanta, 1975, 22, 233.

4. T. Katoh, Bunseki Kagaku, 1953, 2, 402.

5. R. Belcher, A. J. Nutten, and A. M. G. MacDonald, "Quantitative Inorganic Analysis", 3rd ed., 1970, Butterworths Scientific Publications, London, 161.

6. A. Hioki, A. Kokubun, and M. Kubota, Analyst, 1994, 119, 1879.

7. T. Yoshimori and T. Tanaka, Anal. Chim. Acta, 1973, 66, 1973.

8. J. M. Notley, J. Appl. Chem. Biotechnol., 1973, 23, 717. 